\title{
Teaching robotic surgery: Making progress
}

\author{
Mark Onaitis, MD, ${ }^{a}$ and Bernard Park, $\mathrm{MD}^{\mathrm{b}}$
}

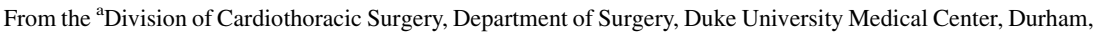 \\ NC; and ${ }^{b}$ Department of Thoracic Surgery, Memorial Sloan-Kettering Cancer Center, New York, NY. \\ Disclosures: M.O. and B.P. disclose that they speak and proctor for Intuitive Surgical, Inc. \\ Received for publication July 4, 2016; accepted for publication July 6, 2016. \\ Address for reprints: Mark Onaitis, MD, DUMC Box 3305, Durham, NC 27710 (E-mail: mwo@ duke.edu). \\ J Thorac Cardiovasc Surg 2016;152:950-1 \\ $0022-5223 / \$ 36.00$ \\ Copyright (c) 2016 by The American Association for Thoracic Surgery \\ http://dx.doi.org/10.1016/j.jtcvs.2016.07.039
}

In this issue of the Journal, the University of Alabama Birmingham group has contributed the first report attempting to demonstrate the ability to teach robotic lobectomy to various levels of trainees in a series of 520 consecutive patients. ${ }^{1}$ The procedure was divided into 19 distinct steps with allotted time limits. Teaching was achieved through real-time feedback, postprocedure debrief, and instructor video review. The overall percentage of learners completing each step was recorded for distinct phases throughout the study period. Successful teaching was demonstrated by an increasing percentage of success. Strengths of the article include clear delineation of the steps of the procedure and definitions of successful completion, the careful measurement of the proportion of trainees completing each step, and the large number of cases involved reflecting the experience and dedication of the senior author. The next steps clearly need to include tracking of individual learners longitudinally over time, identification of essential steps that require mastery to complete an operation independently, and determination of the role of simulation in improving trainee performance.

In the current environment, surgeons are tasked with achieving excellent outcomes while teaching residents who work fewer hours in fewer years of training than ever before. Although minimally invasive surgery (MIS) approaches clearly allow perioperative improvement in outcomes, ${ }^{2,3}$ the possibility for robotic surgery to further reduce incision size and number and to allow more surgeons to transition from traditional open to MIS approaches is real but controversial. ${ }^{4}$ As robotic technology increasingly is being applied to MIS, there is a clear need to develop sound methods to teach index procedures to fellows, residents, and medical students. The current study demonstrates improvements across each of these groups and shows that this type of teaching program can benefit learners at varied levels of experience. Future studies also should include attending surgeons and varied institutions to document individual surgeon learning curve and safe acquisition of skills in different environments.

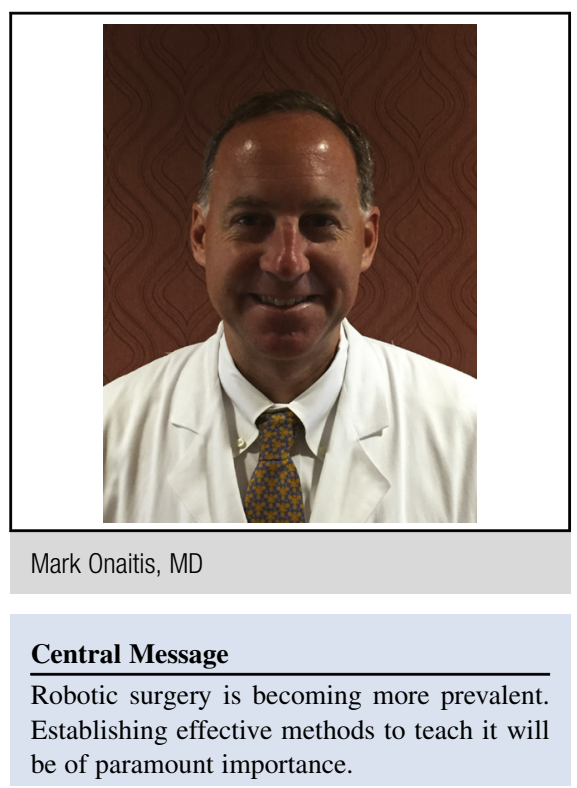

See Article page 991.

Simulation has been demonstrated to improve performance in minimally invasive lobectomy ${ }^{5}$ and clearly will play a key role in the future of surgical training. The simulation experience of the learners in the current study was variable, and future efforts likely should include a more uniform simulation component. Although not procedure-specific, the da Vinci robotic simulator (Intuitive Surgical, Inc, Sunnyvale, Calif) allows objective assessment of learner skills across a series of maneuvers. In cardiac surgery, the addition of a wet laboratory to virtual reality training significantly improved learner performance. ${ }^{6}$ Likewise, given the ease with which MIS procedures are recorded, mandatory video review, ideally by trainee and teacher, should be incorporated in future training paradigms.

Clearly, several important questions remain to be answered regarding increased implementation of robotic technology for MIS lobectomy: What are the advantages of using robotic systems for lobectomy compared with conventional MIS or open techniques and do these justify the additional resources required? Given that robotic technology seems "here to stay," how do we most effectively and safely teach complex procedures to learners of all types? What is the optimal role of simulation and video review in helping learners achieve proficiency? How do we define proficiency sufficient to allow implementation in patients? The current study is an initial attempt to address some of these questions. We must strive for better 
answers to these questions as new robotic platforms enter the market.

\section{References}

1. Cerfolio RJ, Cichos KH, Wei B, Minnich DJ. Robotic lobectomy can be taught while maintaining quality patient outcomes. J Thorac Cardiovasc Surg. 2016;152:991-7.

2. Ceppa DP, Kosinski AS, Berry MF, Tong BC, Harpole DH, Mitchell JD, et al. Thoracoscopic lobectomy has increasing benefit in patients with poor pulmonary function: a Society of Thoracic Surgeons Database analysis. Ann Surg. 2012;256:487-93.
3. Fernandez FG, Kosinski AS, Burfeind W, Park B, DeCamp MM, Seder C, et al The Society of Thoracic Surgeons Lung Cancer Resection Risk Model: higher quality data and superior outcomes. Ann Thorac Surg. 2016;102:370-7.

4. Swanson SJ. Robotic pulmonary lobectomy-the future and probably should remain so. J Thorac Cardiovasc Surg. 2010;140:954.

5. Tong BC, Gustafson MR, Balderson SS, D'Amico TA, Meyerson SL. Validation of a thoracoscopic lobectomy simulator. Eur J Cardiothorac Surg. 2012;42:364-9.

6. Valdis M, Chu MWA, Schlachta C, Kiaii B. Evaluation of robotic cardiac surgery simulation training: a randomized controlled trial. J Thorac Cardiovasc Surg. 2016;151:1498-505.e2.

Access to The Journal of Thoracic and Cardiovascular Surgery Online is reserved for print subscribers!

Full-text access to The Journal of Thoracic and Cardiovascular Surgery Online is available for all print subscribers. To activate your individual online subscription, please visit The Journal of Thoracic and Cardiovascular Surgery Online, point your browser to http://www.mosby.com/itcvs, follow the prompts to activate your online access, and follow the instructions. To activate your account, you will need your subscriber account number, which you can find on your mailing label (note: the number of digits in your subscriber account number varies from 6 to 10 ). See the example below in which the subscriber account number has been circled:

\section{Sample mailing label}

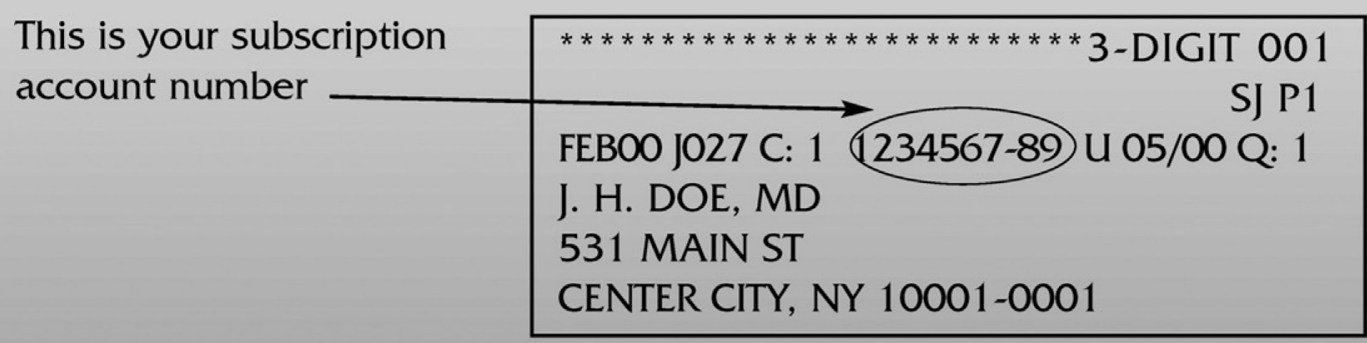

Personal subscriptions to The Journal of Thoracic and Cardiovascular Surgery Online are for individual use only and may not be transferred. Use of The Journal of Thoracic and Cardiovascular Surgery Online is subject to agreement to the terms and conditions as indicated online. 